\title{
Mercury Anomalies Link to Extensive Volcanism Across the Late Devonian Frasnian-Famennian Boundary in South China
}

OPEN ACCESS

Edited by:

Stephen Grasby,

Geological Survey of Canada, Canada

Reviewed by:

Xin-Yuan Zheng,

University of Minnesota Twin Cities,

United States

Yongsheng $\mathrm{He}$,

China University of Geosciences,

China

*Correspondence:

Jiawei Zhang

jiaweizhang@live.cn

Changzhou Deng

dengchangzhou@mail.gyig.ac.cn

Specialty section: This article was submitted to

Geochemistry,

a section of the journa

Frontiers in Earth Science

Received: 07 April 2021 Accepted: 09 June 2021

Published: 06 July 2021

Citation:

Zhang J, Deng C, Liu W, Tang Z, Wang Y, Ye T, Liang W and Liu L (2021) Mercury Anomalies Link to Extensive Volcanism Across the Late Devonian

Frasnian-Famennian Boundary in

South China.

Front. Earth Sci. 9:691827. doi: 10.3389/feart.2021.691827
Jiawei Zhang ${ }^{1,2 *}$, Changzhou Deng ${ }^{3 *}$, Weipeng Liu ${ }^{1}$, Zuoqi Tang ${ }^{2}$, Yue Wang ${ }^{1}$, Taiping Ye ${ }^{4}$, Weian Liang ${ }^{3}$ and Lingyun Liu $^{2}$

${ }^{1}$ College of Resources and Environmental Engineering, Guizhou University, Guiyang, China, ${ }^{2}$ Guizhou Geological Survey, Bureau of Geology and Mineral Exploration and Development of Guizhou Province, Guiyang, China, ${ }^{3}$ State Key Laboratory of Ore Deposit Geochemistry, Institute of Geochemistry, Chinese Academy of Sciences, Guiyang, China, ${ }^{4}$ Guizhou Central Laboratory of Geology and Mineral Resources, Bureau of Geology and Mineral Exploration and Development of Guizhou Province, Guiyang, China

The Late Devonian Frasnian-Famennian ( $F-F)$ mass extinction has been long-time debated by non-volcanic causes, extra-terrestrial impacts, and large igneous province (LIP) eruptions. To better understand the ultimate cause of the F-F mass extinction, here we investigate the chemostratigraphy of mercury $(\mathrm{Hg})$ and total organic carbon (TOC) on two marine F-F strata in the Dushan area, South China. In both sections, high $\mathrm{Hg}$ and $\mathrm{Hg}$ / TOC anomalies were observed near the F-F boundary. These anomalies are in line with those recently observed in Morocco, Germany, Poland, and north Russia, suggesting a global Hg flux. The Late Devonian LIP eruptions, which are believed to have emitted massive amounts of $\mathrm{Hg}$, could be responsible for the global $\mathrm{Hg}$ and $\mathrm{Hg} / \mathrm{TOC}$ anomalies around the F-F boundary. The observed $\mathrm{Hg}$ and $\mathrm{Hg} / \mathrm{TOC}$ anomalies coincide with the extinction of Frasnian fauna in the Dushan area, implying a causal link between the Viluy, Kola, and Pripyat-Dnieper-Donets LIP eruptions and the F-F mass extinction.

Keywords: Hg chemostratigraphy, Kellwasser event, large igneous province, mass extinction, Yangtze

\section{INTRODUCTION}

The Late Devonian Frasnian-Famennian (F-F) transition witnessed one of the "Big Five" mass extinctions which killed at least 40\% of all species during the Phanerozoic (e.g., Stanley, 2016). This critical period was characterized by many global events including climate oscillations (Huang et al., 2018; Liu et al., 2020), eustatic sea-level changes (Sandberg et al., 2002; Bond and Wignall, 2008), atmospheric $\mathrm{O}_{2}$ fluctuation (Dahl et al., 2010), seawater anoxic/hypoxic events (Kellwasser events, Joachimski and Buggisch, 1993), eutrophication events (Murphy et al., 2000), and instability in the sulfate reservoir (Cai et al., 2020). Three main Late Devonian extinction events occurred within an interval of $0.7 \mathrm{Ma}$ from the latest Frasnian to the earliest Famennian stages. These three extinction events were named the Lower Kellwasser Event (372.5 Ma) from the latest Frasnian stage, the Upper Kellwasser Event near the F-F boundary (ca. $372 \mathrm{Ma}$ ), and the Homoctenid Event (371.8 Ma) during the earliest Famennian stage (McGhee and Racki, 2021). Impacts of these events were more severe in low-latitude areas and marine ecosystems, where a fatal impact was caused on shallow-water reefs and fish (McGhee and Racki, 2021). The Late Devonian Viluy LIP (Ricci et al., 2013) in Siberia and the Kola and Pripyat-Dnieper-Donets LIPs (Puchkov et al., 2016) in Baltica are temporally 

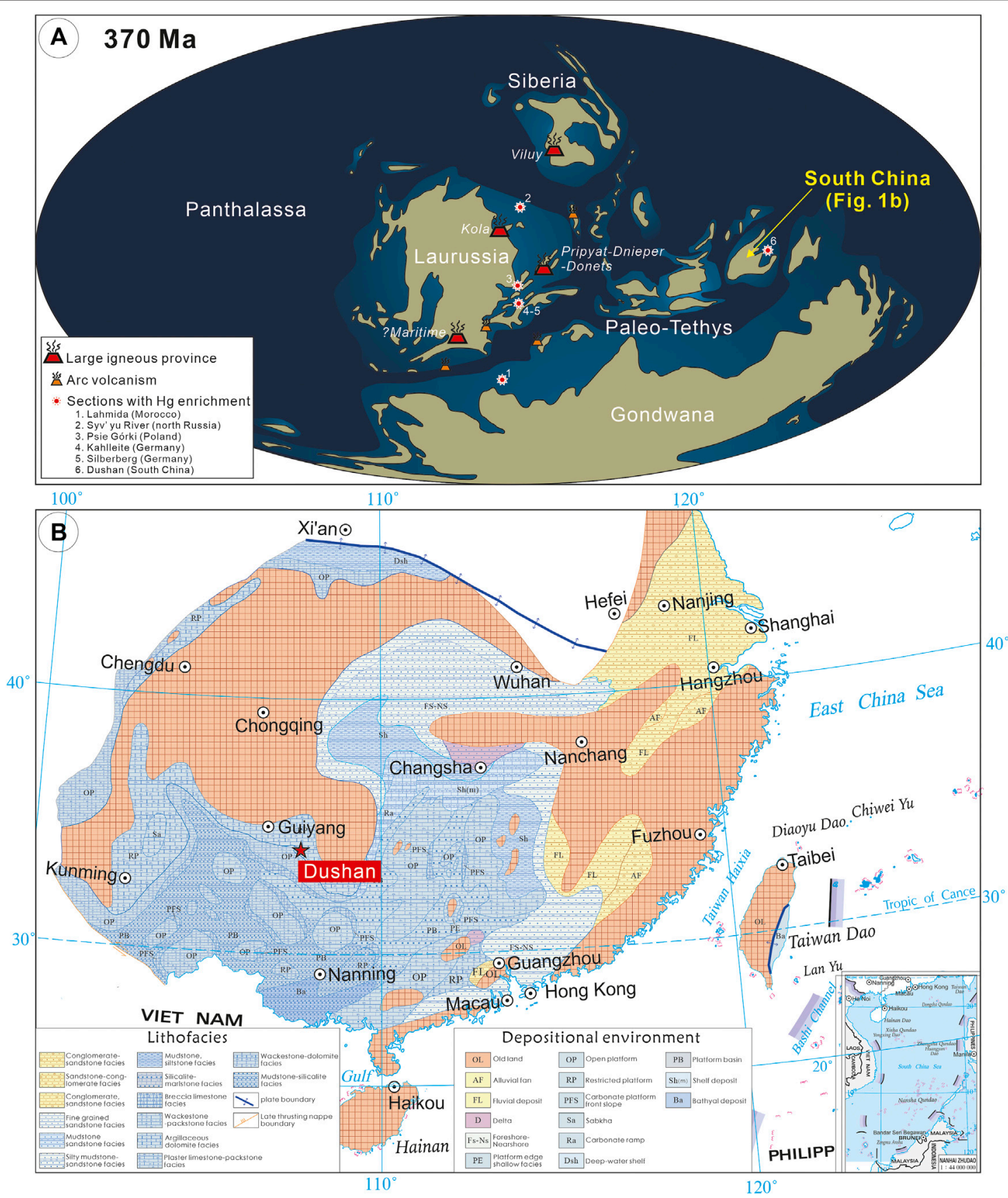

FIGURE 1 | (A) Paleogeographic reconstruction of the Late Devonian (370 Ma). The base map is from Blakey (2016), and assumed locations of coeval igneous activities and Hg enrichment sections are from Racki (2020). (B) Paleogeography of South China during the Late Devonian and location of the Dushan area (modified after Zhao, 1985).

overlapped with the time of Devonian F-F boundary age (Percival et al., 2018a; Da Silva et al., 2020). Climate change, ocean anoxia, and other factors are proposed in concert as the killing mechanisms during these biotic crises (McGhee and Racki, 2021, and references therein), but the ultimate cause of the Late Devonian F-F mass extinction remains somewhat uncertain.
Sedimentary $\mathrm{Hg}$ anomalies have been proven to be used as a new proxy of LIP eruption (Bergquist, 2017; Grasby et al., 2019; Shen et al., 2020). In geological history, $\mathrm{Hg}$ was dominantly emitted to the environment via volcanism and cycled in the atmosphere-land-ocean system before ultimately sinking to the seafloor through organic matter burial (Grasby et al., 2019). Excessive $\mathrm{Hg}$ emission often occurred during LIP eruption, 
resulting in anomalously high $\mathrm{Hg}$ concentration to total organic carbon (Hg/TOC) ratios during critical events (e.g., mass extinction, oceanic anoxia) (Sanei et al., 2012; Grasby et al., 2019).

Compelling evidence of $\mathrm{Hg}$ enrichments in mass extinction horizons has manifested that the end-Ordovician (Gong et al., 2017; Jones et al., 2017), end-Permian (Sanei et al., 2012; Burgess and Bowring, 2015; Grasby et al., 2017, 2020; Shen et al., 2019), end-Triassic (Blackburn et al., 2013; Thibodeau et al., 2016; Percival et al., 2017), end-Cretaceous (Font et al., 2016; Schoene et al., 2019), and Paleocene-Eocene (Keller et al., 2018; Jones et al., 2019) extinctions had a causal link to LIP eruptions. High $\mathrm{Hg}$ anomalies were recently identified close to the Late Devonian F-F boundary from three sections located on the peripheral of Laurussia, implying that the Viluy LIP and other contemporaneous volcanism were the ultimate causes of the F-F mass extinction (Racki et al., 2018). However, to testify whether or not these LIP impacts are global, further examinations on different sections away from the volcanic center remain necessary.

The South China Craton preserves good sedimentary and PaleoBios records for the Upper Kellwasser Event across the F-F boundary (Carmichael et al., 2019, and references therein). This craton was located at the eastern Paleo-Tethys, which was far away from the center of the Late Devonian LIPs based on the global paleogeography reconstruction (Blakey, 2016, Figure 1A). If the Late Devonian volcanism did cause global-scale $\mathrm{Hg}$ perturbation and biota mass extinctions during the F-F interval, it may also have left sedimentary and biotic records in the South China Craton. Monotonous dolomite deposited in the Dushan area of South China during Late Devonian, making it an ideal location for recording the potential volcanic $\mathrm{Hg}$ signal without lithological interference (Bergquist, 2017; Percival et al., 2018b). Here, we report the high-resolution $\mathrm{Hg}$ chemostratigraphy in two continuous successions in the Dushan area to shed light on the correlation between the potential volcanic $\mathrm{Hg}$ signals and the biotic records during the F-F transition.

\section{GEOLOGICAL BACKGROUND}

The South China Craton was located at the eastern part of the Paleo-Tethys Ocean, near the equator during Late Devonian (Blakey, 2016, Figure 1A). It is one of the hotspots for the study of the Devonian system (Carmichael et al., 2019). After the Wuyi-Yunkai intraplate orogeny (Li et al., 2010; Zhang et al., 2016), the Early Devonian (Pragian Stage) transgression followed by the Late Devonian regression gives birth to numerous well-preserved Devonian sections (Figure 1B) and provides ideal sedimentary and PaleoBios records ( $\mathrm{Ma}$ et al., 2016; Qie et al., 2019) for global comparisons (Klapper et al., 1993). The eustatic fall and the mass extinction of the deeper-water brachiopods and conodonts and shallow-water coral and ostracods occurred correlative with the latest Frasnian $\mathrm{Pa}$. linguiformis Zone to the Famennian Lower $P a$. triangularis Zone (Ma et al., 2016). These patterns in South
China are coincident with those of North America (Sandberg et al., 2002). The Late Devonian carbon isotope records of South China are also consistent with those from Gondwana, North America, and Europe (Zhang et al., 2019). A tuffaceous layer just above the F-F boundary from the basinal facies successions in South China yielded a SIMS zircon $\mathrm{U}-\mathrm{Pb}$ age of 367.8 Ma (Zhang et al., 2020), which correlates with the precise F-F boundary age of ca. $372 \mathrm{Ma}$ from Germany (Percival et al., 2018a; Da Silva et al., 2020). Low redox sensitive element concentrations $(\mathrm{Mo}, \mathrm{U}, \mathrm{V})$ and low $\mathrm{V} / \mathrm{Cr}$ ratios $(<2)$ suggest a constant oxic ocean condition in South China during the F-F transition (Zhang et al., 2020). Ocean sulfate deficit (Cai et al., 2020), climate change (Huang et al., 2018), tectonic evolution, and volcanic/hydrothermal activities (Ma et al., 2016; Zhang et al., 2020) have been proposed as the killing mechanisms for F-F mass extinction in South China.

The Late Devonian sequence in the Dushan area represents typical semi-restricted and restricted platform facies which can be correlated with other sections in South China (Ma et al., 2016). Biostratigraphy, paleontology, and lithostratigraphy during the F-F stages have been previously studied (Wang and Chen, 1999; 2006; Nie et al., 2016; Ma et al., 2016). This sequence displays a complete succession through the lastest Frasnian to the early Famennian. The latest Frasnian strata (the middle part of the Sifangpo Member of the Yaosuo Formation) in the Sifangpo (SFP) section are characterized by gray to light gray, medium to thick dolomite bearing abundant body fossils (stromatoporoids, coral, brachiopods). The F-F boundary can be roughly determined by a prominent stratigraphic transformational surface above the Frasnian fauna disappeared horizon which is also the horizon of sample SFP320 (Wang and Chen, 1999; 2006). Body fossils disappeared near the F-F boundary. The earliest Famennian sequence (the middle part of the Sifangpo Member of the Yaosuo Formation) consists of light gray to grayish-white, thin- and medium-bedded dolomite and yields a few trace fossils (Wang et al., 2006). Locally hydrothermal and volcanic activities are absent in the Dushan area (GGS, 2017). Therefore, the well-preserved sedimentary and fossil records in the Dushan area (Figure 2) show a unique advantage for studying the direct association between the potential volcanic activities and the Late Devonian mass extinctions.

\section{METHODS}

Both the fossil-rich SFP section (N 25 $51^{\prime} 30.7^{\prime \prime}$, E $107^{\circ} 32^{\prime} 11.3^{\prime \prime}$ ) and the fossil-poor Shenheqiao (SHQ) section (N 25 $55^{\prime} 4.8^{\prime \prime}, \mathrm{E}$ $\left.107^{\circ} 32^{\prime} 59^{\prime \prime}\right)$ in the Dushan area were selected in this study. Flesh rock samples (27 samples from the SFP section and 16 samples from the SHQ section) were systematically collected near the F-F boundary from both sections with an interval of $10-20 \mathrm{~cm}$ (Figure 2). After removing the weathered surfaces, thin sections were prepared from 14 samples from the SFP section. The remaining samples were powdered to 200 mesh by the agate mortar for the following analytical testing. 


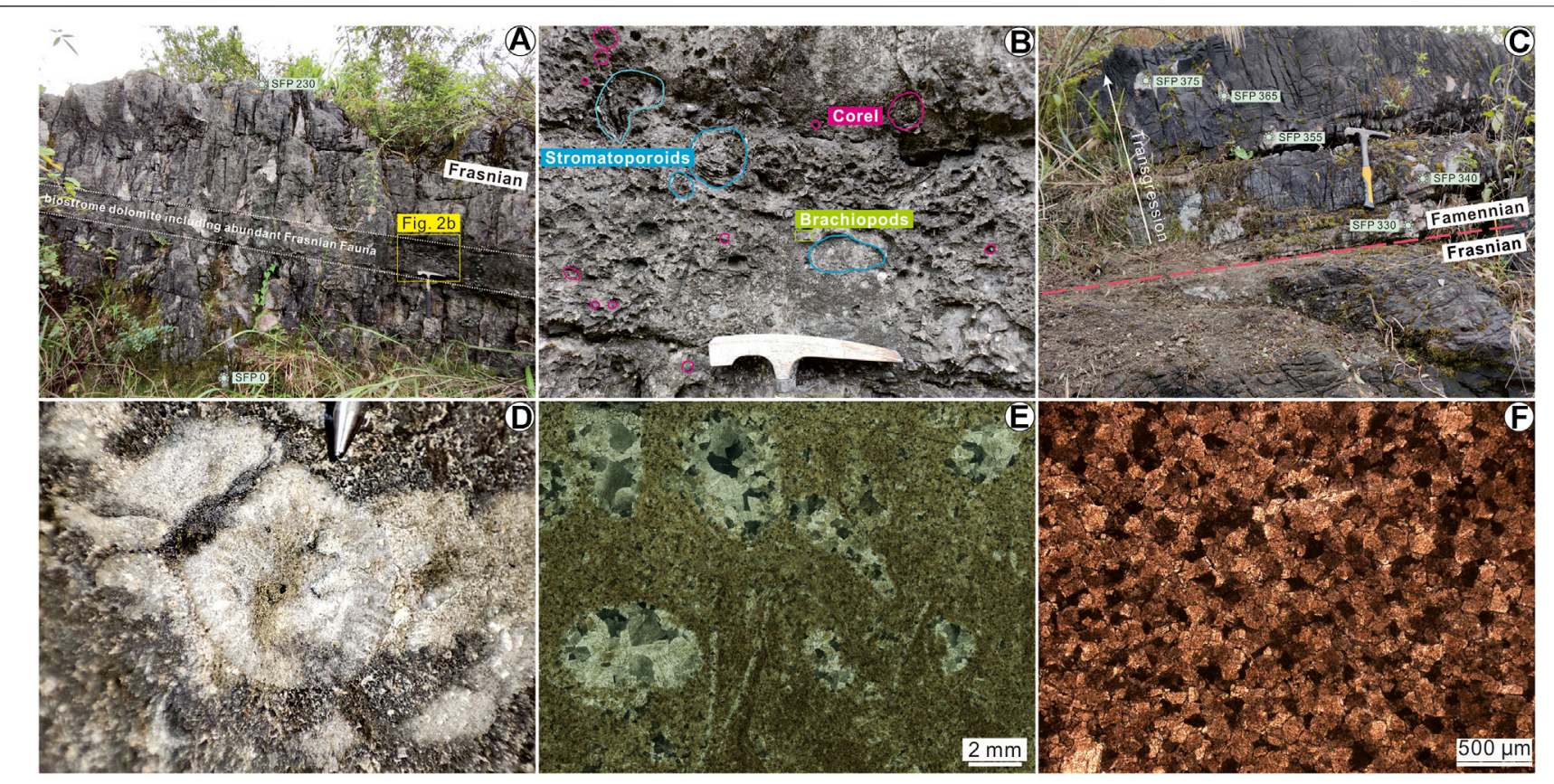

FIGURE 2 | (A) Field photo of Sifangpo section, Dushan area, showing biostrome dolomite. (B) Detailed view of biostrome dolomite at 2.4-2.6 m below the F-F boundary, showing abundant body fossils including stromatoporoids, coral, and brachiopods. (C) F-F boundary (dashed line) in the dolostone sequence, emphasizing the transgression that occurred during the earliest Famennian. (D) Close view of coral in latest Frasnian strata. (E) Thin-section photo of sample SFP85, emphasizing the abundance of dolomitic body fossils. (F) Thin-section photo of sample SFP320, emphasizing dolomite is the dominant rock-forming mineral.

\section{Optical and FESEM-EDS Mineralogy Microscopy}

Optical and field emission scanning electron microscope imaging of the 14 thin sections was performed at the Center for Lunar and Planetary Sciences, Institute of Geochemistry, Chinese Academy of Sciences, using an FEI Scios DualBeam field emission scanning electron microscope system, which was equipped with EDAX energy dispersive spectroscopy (FESEM-EDS). The backscatter electron mode analysis and energy dispersive spectroscopy point analysis were carried out at $20 \mathrm{kV}$.

\section{$\mathrm{Hg}$ Concentration Analysis}

The sample powders were analyzed for $\mathrm{Hg}$ concentrations using a Lumex $\mathrm{Hg}$ analyzer RA 915F with the $\mathrm{Hg}$ detection limit of $0.5 \mathrm{ng} / \mathrm{g}$ at the State Key Laboratory of Ore Deposit Geochemistry, Institute of Geochemistry, Chinese Academy of Sciences. Measurements of the standard reference material (GSS4, soil) yielded $\mathrm{Hg}$ recoveries of 90 and $110 \%$, and coefficients of variation for triplicate analyses were $<10 \%$.

\section{Total Organic Carbon Content Analysis}

Total organic carbon (TOC, wt\%) analyses were carried out using the same samples previously used for analyzing $\mathrm{Hg}$ concentrations, using the potassium dichromate method (Schumacher, 2002). The sample powders were first leached by $2.5 \mathrm{~N} \mathrm{HCl}$ to remove inorganic carbon and then rinsed by $18.2 \mathrm{M} \Omega \mathrm{cm}$ water, freeze-dried, and measured using an
Elementar vario MICRO cube analyzer with analytical errors $<2.5 \%$.

\section{X-Ray Diffractometry Analysis}

The mineralogy composition was performed on 27 powder samples (SFP) using a Rigaku Ultima IV X-ray diffractometer, with a carbon monochromator and $\mathrm{Cu}-\mathrm{Ka}$ radiation, at $40 \mathrm{kV}$ and $40 \mathrm{~mA}$ at Guizhou Central Laboratory of Geology and Mineral Resources, Bureau of Geology and Mineral Exploration and Development of Guizhou Province. Mineral composition was determined on randomly oriented powdered samples. The diffraction patterns were processed using Jade 6.5 software, and the primitive modal contents were calculated by the Rietveld method.

\section{RESULTS}

\section{Mineral Composition Results}

The mineralogy composition (in wt\%) is presented in Table $\mathbf{1 .}$ Samples from both SFP and SHQ sections are fine- to mediumgrained dolostones. The rocks mainly consist of dolomite (88-97\%) with minor illite, zeolite, calcite, quartz, variable fossil fragments, and organic matter. Dolomite exhibited poikilitic texture and is $0.1-0.2 \mathrm{~mm}$ in size. Clay minerals and authigenic quartz are mainly distributed between dolomite. Fossil fragments can be found in the thin sections of SFP0 to SFP290 and disappeared in the thin sections of SFP300 to SFP400. 
TABLE 1 | Hg (ppb), TOC (\%), Hg/TOC (ppb/\%) and mineral compositions (wt\%) of samples from the Sifangpo (SFP) and Shenheqiao (SHQ) sections, Dushan, South China.

\begin{tabular}{|c|c|c|c|c|c|c|c|c|c|}
\hline Sample & Lithology & $\frac{\mathrm{Hg}}{\mathrm{ppb}}$ & $\frac{\text { TOC }}{\%}$ & $\frac{\mathrm{Hg} / \mathrm{TOC}}{\mathrm{ppb} / \%}$ & $\frac{\text { Dolomite }}{w t \%}$ & $\frac{\text { Calcite }}{w t \%}$ & $\frac{\text { Zeolite }}{w t \%}$ & $\frac{\text { Quartz }}{w t \%}$ & $\frac{\text { Illite }}{\text { wt } \%}$ \\
\hline SFPO & Dolomite & 4.1 & 2.56 & 1.6 & 91.4 & 0 & 3.6 & 0 & 5 \\
\hline SFP20 & Dolomite & 6.5 & 3.83 & 1.7 & 94.2 & 0.2 & 3.4 & 0 & 2.2 \\
\hline SFP50 & Dolomite & 6.5 & 5.41 & 1.2 & 93.6 & 0.1 & 3.2 & 1 & 2.1 \\
\hline SFP70 & Dolomite & 11.3 & 1.92 & 5.9 & 81.8 & 11.2 & 4.3 & 0.5 & 2.2 \\
\hline SFP85 & Dolomite & 10.6 & 5.7 & 1.9 & 89.9 & 2.4 & 4.9 & 1.3 & 1.5 \\
\hline SFP110 & Dolomite & 10.4 & 0.33 & 31.1 & 96.9 & 0.2 & 2 & 0.9 & 0 \\
\hline SFP130 & Dolomite & 7.4 & 4.31 & 1.7 & 93 & 0.7 & 2.9 & 0.3 & 3.1 \\
\hline SFP150 & Dolomite & 4.1 & 5.28 & 0.8 & 96.4 & 0.1 & 2.5 & 0.7 & 0.3 \\
\hline SFP170 & Dolomite & 14.7 & 4.24 & 3.5 & 92.7 & 0.2 & 4.3 & 0.5 & 2.3 \\
\hline SFP190 & Dolomite & 3.4 & 0.57 & 6 & 91.3 & 0.6 & 3.5 & 0 & 4.6 \\
\hline SFP210 & Dolomite & 8.6 & 4.03 & 2.1 & 93.4 & 0.2 & 2.7 & 0 & 3.7 \\
\hline SFP230 & Dolomite & 11.6 & 5.02 & 2.3 & 91.3 & 0.6 & 4.2 & 0 & 3.9 \\
\hline SFP240 & Dolomite & 7.1 & 2.76 & 2.6 & 94.7 & 0 & 3.6 & 0 & 1.7 \\
\hline SFP250 & Dolomite & 11.7 & 1.59 & 7.4 & 92.3 & 0 & 3.4 & 0 & 4.3 \\
\hline SFP260 & Dolomite & 13.9 & 3.81 & 3.7 & 92.9 & 0.1 & 4.2 & 0 & 2.8 \\
\hline SFP275 & Dolomite & 6.7 & 6.45 & 1 & 96.7 & 0.2 & 2.6 & 0 & 0.5 \\
\hline SFP290 & Dolomite & 2.8 & 0.67 & 4.2 & 96.9 & 0 & 2.5 & 0 & 0.6 \\
\hline SFP300 & Dolomite & 21.3 & 1.3 & 16.4 & 92.3 & 0 & 4.5 & 0.8 & 2.4 \\
\hline SFP310 & Dolomite & 23.8 & 1.3 & 18.3 & 93.2 & 1.5 & 3.5 & 0.8 & 1 \\
\hline SFP320 & Dolomite & 20 & 0.34 & 59.1 & 96.5 & 0.1 & 1.4 & 0.9 & 1.1 \\
\hline SFP330 & Dolomite & 14.2 & 1.09 & 13 & 90.3 & 0 & 1.2 & 1.9 & 6.6 \\
\hline SFP340 & Dolomite & 8.5 & 0.44 & 19.3 & 87.9 & 3.6 & 4.4 & 0.6 & 3.5 \\
\hline SFP355 & Dolomite & 5 & 0.32 & 15.8 & 95 & 0 & 3.5 & 0.9 & 0.6 \\
\hline SFP365 & Dolomite & 3.5 & 2.85 & 1.2 & 93.2 & 0.2 & 3 & 1.8 & 1.8 \\
\hline SFP375 & Dolomite & 6 & 4.83 & 1.2 & 93.9 & 0 & 3.4 & 0.5 & 2.2 \\
\hline SFP385 & Dolomite & 7.7 & 2.79 & 2.7 & 96.1 & 0.1 & 3.2 & 0 & 0.6 \\
\hline SFP400 & Dolomite & 5.4 & 0.28 & 19.4 & 96 & 0.1 & 3.2 & 0.4 & 0.3 \\
\hline SHQ380 & Dolomite & 20.3 & 0.18 & 110.2 & & & & & \\
\hline SHQ400 & Dolomite & 9.7 & 0.08 & 128.3 & & & & & \\
\hline SHQ410 & Dolomite & 7.7 & 0.07 & 106.7 & & & & & \\
\hline SHQ420 & Dolomite & 1.1 & 0.15 & 7.6 & & & & & \\
\hline SHQ430 & Dolomite & 34.5 & 0.21 & 161.7 & & & & & \\
\hline SHQ445 & Dolomite & 10.6 & 0.2 & 52.2 & & & & & \\
\hline SHQ450 & Dolomite & 10.2 & 0.17 & 59.9 & & & & & \\
\hline SHQ460 & Dolomite & 11.2 & 0.21 & 54.5 & & & & & \\
\hline SHQ470 & Dolomite & 43.1 & 0.19 & 221 & & & & & \\
\hline SHQ475 & Dolomite & 35.6 & 0.14 & 250.9 & & & & & \\
\hline SHQ500 & Dolomite & 6.4 & 0.16 & 39.3 & & & & & \\
\hline SHQ510 & Dolomite & 7.3 & 0.06 & 122.8 & & & & & \\
\hline SHQ520 & Dolomite & 3.5 & 0.23 & 14.8 & & & & & \\
\hline SHQ530 & Dolomite & 5.5 & 0.14 & 39.4 & & & & & \\
\hline SHQ540 & Dolomite & 3.9 & 0.36 & 11 & & & & & \\
\hline SHQ550 & Dolomite & 3.8 & 1.46 & 2.6 & & & & & \\
\hline
\end{tabular}

\section{$\mathrm{Hg}$ and $\mathrm{TOC}$ Concentrations}

Samples from the SFP section have $\mathrm{Hg}$ concentrations ranging from 2.83 to $23.8 \mathrm{ppb}$ with a median value of $7.66 \mathrm{ppb}$. These samples have variable TOC contents ranging from 0.28 to $6.45 \%$, which are broadly consistent with the fossil abundance from field observation. $\mathrm{Hg} / \mathrm{TOC}$ values range from 0.79 to 59.1 with a median value of 3.47. Hg displays weak correlations with TOC $(r=-0.19)$, whereas $\mathrm{Hg} / \mathrm{TOC}$ shows positive correlations with $\mathrm{Hg}$ $(r=+0.51)$ and negative correlations with TOC $(r<-0.64)$ (Figure 3).

Samples from the SHQ section have $\mathrm{Hg}$ concentrations ranging from 1.12 to $43.1 \mathrm{ppb}$ with a median value of $9.68 \mathrm{ppb}$ and relatively low TOC contents $(0.06-1.34 \%)$. To provide meaningful interpretation, three extremely low-TOC
$(<0.1 \%)$ samples are eliminated from the discussion (Grasby et al., 2019; Shen et al., 2020). Hg/TOC ratios of these samples range from 2.58 to 251 with a background value of 52.2. Hg and TOC are insignificantly correlated $(r=-0.25)$, and $\mathrm{Hg} / \mathrm{TOC}$ displays significant positive correlations with $\mathrm{Hg}$ $(r=+0.97)$ but weak correlations with TOC $(r<-0.32)$ (Figure 3).

\section{DISCUSSION AND CONCLUSION}

Subaerial volcanism serves as the major natural source of $\mathrm{Hg}$ in the environment, with a normal annual flux of 75-700 tons (Grasby et al., 2019). Volcanism emits massive amounts of $\mathrm{Hg}$ 

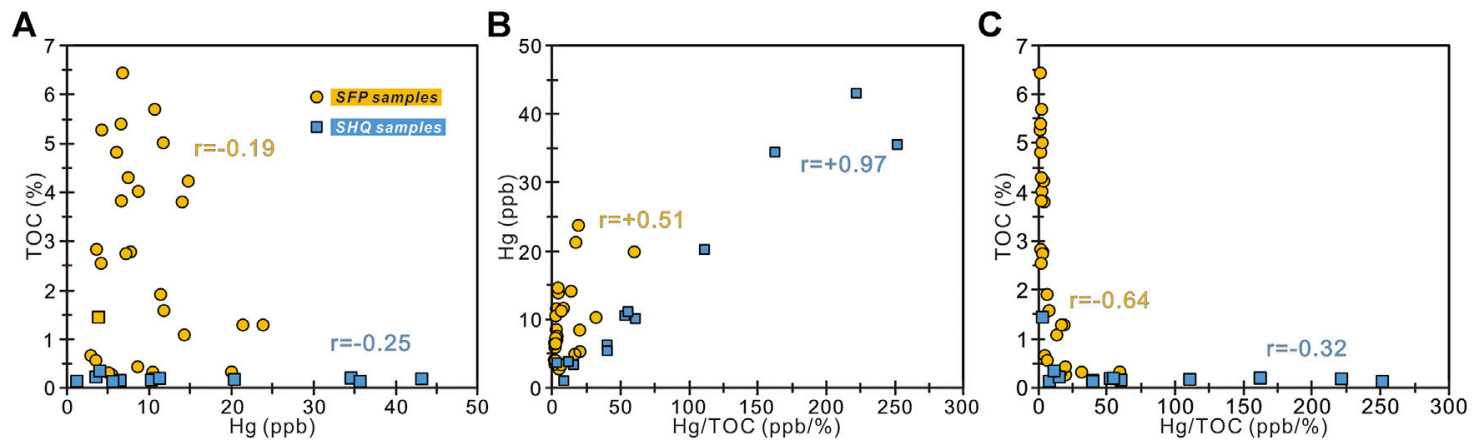

FIGURE 3 | Cross plot of (A) TOC vs. Hg, (B) Hg vs. Hg/TOC, and (C) TOC vs. Hg/TOC.

to the atmosphere, in the form of gaseous $\operatorname{Hg}(0)$. This form of $\mathrm{Hg}$ has a lifetime of $\sim 1$ year in the atmosphere, allowing this element to be globally and uniformly distributed before deposition into marine and terrestrial ecosystems (Percival et al., 2017). Once deposited, $\mathrm{Hg}$ continues to cycle in the atmosphere-land-ocean system, but it ultimately sinks to the seafloor. Organic matter (OM) drawdown plays a critical role in $\mathrm{Hg}$ burial onto the seafloor due to its strong affinity to $\mathrm{Hg}$ (Sanei et al., 2012; Grasby et al., 2019). Under normal conditions, volcanic $\mathrm{Hg}$ emissions can be balanced by $\mathrm{OM}$ drawdown; however, excessive $\mathrm{Hg}$ emission often occurred during LIP eruption, resulting in high $\mathrm{Hg}$ concentration to TOC (Hg/TOC) ratios during critical events such as mass extinction events and/or oceanic anoxia events (Sanei et al., 2012; Blackburn et al., 2013; Burgess and Bowring, 2015; Font et al., 2016; Thibodeau et al., 2016; Gong et al., 2017; Jones et al., 2017; Percival et al., 2017; Keller et al., 2018; Jones et al., 2019; Schoene et al., 2019; Grasby et al., 2020; Shen et al., 2020).

To be noticed, clay minerals (Kongchum et al., 2011; Uddin, 2017), sulfides (Bower et al., 2008; Duan et al., 2016; Shen et al., 2020), and Fe-Mn oxides (Quémerais et al., 1998) are also important hosts of $\mathrm{Hg}$ in marine sediments. Small $\mathrm{Hg}$ fluxes can be a localized source from the submarine volcanic and hydrothermal activity limited to vicinity of the eruption or emission center (Scaife et al., 2017; Moreno et al., 2018; Jones et al., 2019), wildfire (Shen et al., 2011), or erosion (Them et al., 2019). Therefore, special attention must be paid to determine whether $\mathrm{Hg}$ anomalies are attributed to increased volcanic $\mathrm{Hg}$ loading, or other $\mathrm{Hg}$ enrichment mechanisms (Sanei et al., 2012; Grasby et al., 2019; Shen et al., 2020). In this study, given sulfides were not detected by X-ray diffractometry and the correlation between $\mathrm{Hg}$ concentrations and main rockforming minerals (dolomite, illite) is insignificant (not shown), manifesting these minerals are not the main hosts of $\mathrm{Hg}$. $\mathrm{Hg}$ displays weak correlation with TOC (Figure 3A), and $\mathrm{Hg} / \mathrm{TOC}$ peaks are more correlative with the $\mathrm{Hg}$ peaks rather than TOC peaks (Figures 3B,C) in both sections, which indicates that $\mathrm{Hg}$ is unlikely related to localized organic matter detention (Grasby et al., 2019). The Hg/TOC values from both sections exhibit rhythmic and comparable variation through time, strongly supporting that the $\mathrm{Hg}$ enrichments in sediments are not associated with organic matter, redox conditions (e.g., Shen et al., 2020), or secondary weathering in random layers. The lithological and mineralogical similarity across the $\mathrm{Hg}$ and $\mathrm{Hg} / \mathrm{TOC}$ peak horizons in both sections demonstrates that the terrestrial inputs, sedimentation rate, and diagenesis process are not the main causes for the observed $\mathrm{Hg}$ anomalies. In both sections, the $\mathrm{Hg}$ /TOC peaks correlate well with the $\mathrm{Hg}$ peaks near the F-F boundary (Figure 4), suggesting excessive $\mathrm{Hg}$ inputs to the ocean were responsible for the high $\mathrm{Hg} / \mathrm{TOC}$ anomalies during the F-F transition. Two spurious $\mathrm{Hg} / \mathrm{TOC}$ ratio peaks at $0.8 \mathrm{~m}$ above and $3.1 \mathrm{~m}$ below the $\mathrm{F}-\mathrm{F}$ boundary were due to low TOC content rather than elevated supply of $\mathrm{Hg}$ (Figure 4).

Racki et al. (2018) suggested three criterions for detection of the real volcanic $\mathrm{Hg}$ signal in the sedimentary sequence: (1) Hg enriched above $3 \times$ the median $\mathrm{Hg}$ content, (2) $\mathrm{Hg} / \mathrm{TOC}$ enriched above $3 \times$ the median $\mathrm{Hg} / \mathrm{TOC}$ content, and (3) $\mathrm{Hg}$ abnormal identified worldwide. In this study, the SFP section shows the highest $\mathrm{Hg}$ enrichment of $3.1 \times$ the background while the highest $\mathrm{Hg} / \mathrm{TOC}$ enrichment of $5.7 \times$ the background at the F-F boundary. Compatible $\mathrm{Hg}$ and $\mathrm{Hg}$ / TOC enrichments can be observed in the SHQ section (Figure 4). Localized volcanic and hydrothermal activities are limited in the Dushan area (GGS, 2017) which preclude the possibility of a local volcanic or submarine $\mathrm{Hg}$ contribution. Exotic volcanic matter was identified throughout the F-F boundary succession in the basinal facies in South China (Zhang et al., 2020), which indicated extensive volcanic activities occurred beyond South China during the $\mathrm{F}-\mathrm{F}$ transition. Moreover, the $\mathrm{Hg}$ anomalies just under the F-F boundary have also been reported previously in Morocco, Germany, Poland, and north Russia (Racki et al., 2018; Racki, 2020). Although the low Hg contents in South China than other sections worldwide may be due to the effectiveness of different lithology in archiving the $\mathrm{Hg}$ record (Bergquist, 2017; Percival et al., 2018b), the $\mathrm{Hg}$ and $\mathrm{Hg} / \mathrm{TOC}$ enrichments observed in our study are in line with 

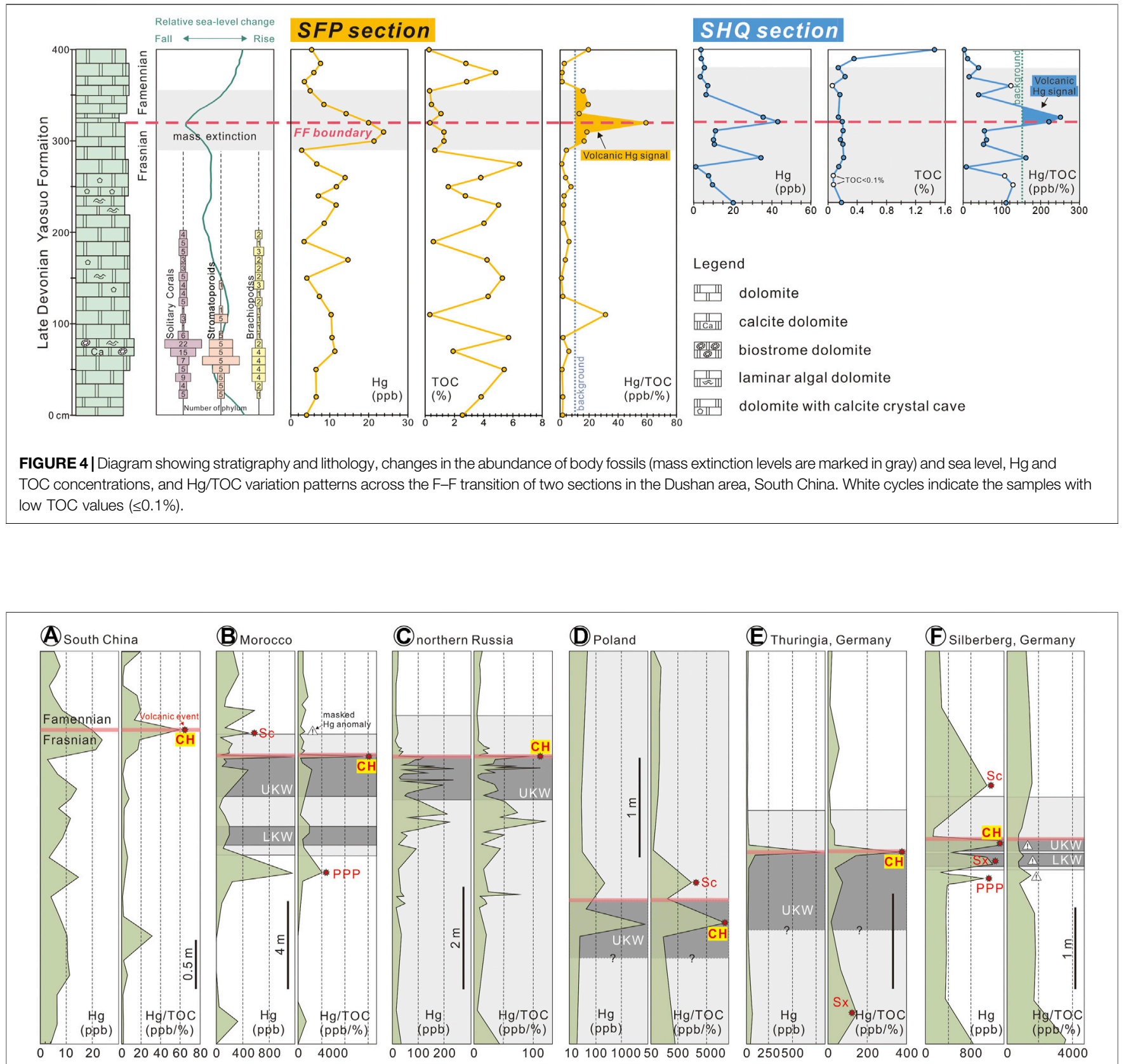

FIGURE 5|F-F sections in (A) South China, (B) Morocco, (C) north Russia, (D) Poland, (E) Thuringia, Germany, and (F) Silberberg, Germany (modified after Racki et al., 2018; Racki, 2020) showing Hg enrichments with highlights on their probable correlation with bentonite beds by Winter (2015). Abbreviation: CH, Center Hill; Sc, Scorpius; Sx, Sextans, PPP, Pictor-Phoenix-Pegasus.

those observed in other sections worldwide (Figure 5). An ash bed named Center Hill Ash coincidently occurred in the US just prior to the F-F boundary based on associated conodonts (Over, 2002). Thus, the observed global Hg anomalies are tentatively correlated with the volcanic activities which produce the Center Hill Ash Bed (Racki, 2020). Considering the correlation of the complex global Hg patterns (Figure 5) and the age of Devonian LIPs (Ricci et al., 2013; Puchkov et al., 2016; Ernst et al., 2020), we suggest the Hg perturbation in sediments is induced by the eruptions of the Late Devonian Viluy, Kola, and Pripyat-Dnieper-Donets LIPs.

Volcanic activity can release massive $\mathrm{CO}_{2}$ and geothermic gas into the atmosphere which could cause synergistic effects of global warming, ocean anoxia, acidification, and eventually marine mass extinction (Clapham and Renne, 2019; McGhee and Racki, 2021; Racki, 2021). The studied F-F volcanic Hg signals are stratigraphically tied to the extinction of Frasnian fauna and decline of organic matter (Figure 4), supporting a 
causal link between global massive volcanism and biodiversity crisis, which further strengthens the hypothesis for LIP volcanism as the ultimate driver of F-F mass extinction.

\section{DATA AVAILABILITY STATEMENT}

The original contributions presented in the study are included in the article/supplementary material, and further inquiries can be directed to the corresponding authors.

\section{AUTHOR CONTRIBUTIONS}

$\mathrm{JZ}$ and CD contributed to conception, design, and fund of the study. JZ, CD, ZT, YW, and LL carried out the field geological survey and sampling. CD, WPL, WAL, and TY performed sample preparation

\section{REFERENCES}

Bergquist, B. A. (2017). Mercury, Volcanism, and Mass Extinctions. Proc. Natl. Acad. Sci. USA 114, 8675-8677. doi:10.1073/pnas.1709070114

Blackburn, T. J., Olsen, P. E., Bowring, S. A., McLean, N. M., Kent, D. V., Puffer, J., et al. (2013). Zircon U-Pb Geochronology Links the End-Triassic Extinction with the Central Atlantic Magmatic Province. Science 340, 941-945. doi:10.1126/science. 1234204

Blakey, R. (2016). "Devonian - 370 Ma, Global Paleogeography and Tectonics in Deep Time Series," in Deep Time Maps ${ }^{\mathrm{TM}}$ Paleogeography.

Bond, D. P. G., and Wignall, P. B. (2008). The Role of Sea-Level Change and marine Anoxia in the Frasnian-Famennian (Late Devonian) Mass Extinction. Palaeogeogr. Palaeoclimatol. Palaeoecol. 263, 107-118. doi:10.1016/j.palaeo.2008.02.015

Bower, J., Savage, K. S., Weinman, B., Barnett, M. O., Hamilton, W. P., and Harper, W. F. (2008). Immobilization of Mercury by Pyrite (FeS2). Environ. Pollut. 156, 504-514. doi:10.1016/j.envpol.2008.01.011

Burgess, S. D., and Bowring, S. A. (2015). High-precision Geochronology Confirms Voluminous Magmatism before, during, and after Earth's Most Severe Extinction. Sci. Adv. 1, e1500470. doi:10.1126/sciadv.1500470

Cai, C., Xu, C., Fakhraee, M., Chen, D., Li, K., and Jiang, L. (2020). Significant Fluctuation in the Global Sulfate Reservoir and Oceanic Redox State during the Late Devonian Mass Extinction. Preprint (Version 1). doi:10.21203/rs.3.rs-116321/v1

Carmichael, S. K., Waters, J. A., Königshof, P., Suttner, T. J., and Kido, E. (2019). Paleogeography and Paleoenvironments of the Late Devonian Kellwasser Event: A Review of its Sedimentological and Geochemical Expression. Glob. Planet. Change 183, 102984. doi:10.1016/j.gloplacha.2019.102984

Clapham, M. E., and Renne, P. R. (2019). Flood Basalts and Mass Extinctions. Annu. Rev. Earth Planet. Sci. 47, 275-303. doi:10.1146/annurev-earth-053018-060136

Da Silva, A.-C., Sinnesael, M., Claeys, P., Davies, J. H. F. L., De Winter, N. J., Percival, L. M. E., et al. (2020). Anchoring the Late Devonian Mass Extinction in Absolute Time by Integrating Climatic Controls and Radio-Isotopic Dating. Sci. Rep. 10, 12940. doi:10.1038/s41598-020-69097-6

Dahl, T. W., Hammarlund, E. U., Anbar, A. D., Bond, D. P. G., Gill, B. C., Gordon, G. W., et al. (2010). Devonian Rise in Atmospheric Oxygen Correlated to the Radiations of Terrestrial Plants and Large Predatory Fish. Proc. Natl. Acad. Sci. 107, 17911-17915. doi:10.1073/pnas.1011287107

Duan, Y., Han, D. S., Batchelor, B., and Abdel-Wahab, A. (2016). Synthesis, Characterization, and Application of Pyrite for Removal of Mercury. Colloids Surf. A: Physicochemical Eng. Aspects 490, 326-335. doi:10.1016/j.colsurfa.2015.11.057

Ernst, R. E., Rodygin, S. A., and Grinev, O. M. (2020). Age Correlation of Large Igneous Provinces with Devonian Biotic Crises. Glob. Planet. Change 185, 103097. doi:10.1016/j.gloplacha.2019.103097

Font, E., Adatte, T., Sial, A. N., Drude de Lacerda, L., Keller, G., and Punekar, J. (2016). Mercury Anomaly, Deccan Volcanism, and the End-Cretaceous Mass Extinction. Geology 44, 171-174. doi:10.1130/g37451.1 and data analysis. JZ wrote the first draft of the manuscript. All authors contributed to manuscript revision and read and approved the submitted version.

\section{FUNDING}

This work was financially supported by the National Natural Science Foundation of China (41762001), Guizhou Scientific and Technology Fund (QKHJZ(2015)2081), and Guizhou Scientific and Technology Planning Project (QKHZC(2020)4Y034).

\section{ACKNOWLEDGMENTS}

We thank editor Stephen Grasby and two anonymous reviewers for constructive reviews.

GGS (2017). Regional Geological of China. Beijing: Geological Press.

Gong, Q., Wang, X., Zhao, L., Grasby, S. E., Chen, Z.-Q., Zhang, L., et al. (2017). Mercury Spikes Suggest Volcanic Driver of the Ordovician-Silurian Mass Extinction. Sci. Rep. 7, 53. doi:10.1038/s41598-017-05524-5

Grasby, S. E., Liu, X., Yin, R., Ernst, R. E., and Chen, Z. (2020). Toxic Mercury Pulses into Late Permian Terrestrial and marine Environments. Geology 48, 830-833. doi:10.1130/g47295.1

Grasby, S. E., Shen, W., Yin, R., Gleason, J. D., Blum, J. D., Lepak, R. F., et al. (2017). Isotopic Signatures of Mercury Contamination in Latest Permian Oceans. Geology 45, 55-58. doi:10.1130/G38487.1

Grasby, S. E., Them, T. R., Chen, Z., Yin, R., and Ardakani, O. H. (2019). Mercury as a Proxy for Volcanic Emissions in the Geologic Record. Earth-Science Rev. 196, 102880. doi:10.1016/j.earscirev.2019.102880

Huang, C., Joachimski, M. M., and Gong, Y. (2018). Did Climate Changes Trigger the Late Devonian Kellwasser Crisis? Evidence from a High-Resolution Conodont $818 \mathrm{OPO} 4$ Record from South China. Earth Planet. Sci. Lett. 495, 174-184. doi:10.1016/j.epsl.2018.05.016

Joachimski, M. M., and Buggisch, W. (1993). Anoxic Events in the Late Frasnian Causes of the Frasnian Famennian Faunal Crisis? Geology 21, 675-678. doi:10.1130/0091-7613(1993)021<0675:aeitlf >2.3.CO;2

Jones, D. S., Martini, A. M., Fike, D. A., and Kaiho, K. (2017). A Volcanic Trigger for the Late Ordovician Mass Extinction? Mercury Data from south China and Laurentia. Geology 45, 631-634. doi:10.1130/g38940.1

Jones, M. T., Percival, L. M. E., Stokke, E. W., Frieling, J., Mather, T. A., Riber, L., et al. (2019). Mercury Anomalies across the Palaeocene-Eocene Thermal Maximum. Clim. Past 15, 217-236. doi:10.5194/cp-15-217-2019

Keller, G., Mateo, P., Punekar, J., Khozyem, H., Gertsch, B., Spangenberg, J., et al. (2018). Environmental Changes during the Cretaceous-Paleogene Mass Extinction and Paleocene-Eocene thermal Maximum: Implications for the Anthropocene. Gondwana Res. 56, 69-89. doi:10.1016/ j.gr.2017.12.002

Klapper, G., Feist, R., Becker, R. T., and House, M. R. (1993). Definition of the Frasnian/Famennian Stage Boundary. Episodes 16, 433-441. doi:10.18814/ epiiugs/1993/v16i4/003

Kongchum, M., Hudnall, W. H., and Delaune, R. D. (2011). Relationship between Sediment clay Minerals and Total Mercury. J. Environ. Sci. Health A 46, 534-539. doi:10.1080/10934529.2011.551745

Li, Z. X., Li, X. H., Wartho, J. A., Clark, C., Li, W. X., Zhang, C. L., et al. (2010). Magmatic and Metamorphic Events during the Early Paleozoic Wuyi-Yunkai Orogeny, southeastern South China: New Age Constraints and PressureTemperature Conditions. Geol. Soc. America Bull. 122, 772-793. doi:10.1130/b30021.1

Liu, Z., Selby, D., Hackley, P. C., and Over, D. J. (2020). Evidence of Wildfires and Elevated Atmospheric Oxygen at the Frasnian-Famennian Boundary in New York (USA): Implications for the Late Devonian Mass Extinction. GSA Bull. 132, 2043-2054. doi:10.1130/b35457.1 
Ma, X., Gong, Y., Chen, D., Racki, G., Chen, X., and Liao, W. (2016). The Late Devonian Frasnian-Famennian Event in South China-Patterns and Causes of Extinctions, Sea Level Changes, and Isotope Variations. Palaeogeogr. Palaeoclimatol. Palaeoecol. 448, 224-244. doi:10.1016/j.palaeo.2015.10.047

McGhee, G. R., and Racki, G. (2021). Extinction: Late Devonian Mass Extinction. Paleontology 2, 1-8. doi:10.1002/9780470015902.a0029301

Moreno, C., González, F., Sáez, R., Melgarejo, J. C., and Suárez-Ruiz, I. (2018). The Upper Devonian Kellwasser Event Recorded in a Regressive Sequence from Inner Shelf to Lagoonal Pond, Catalan Coastal Ranges, Spain. Sedimentology 65, 2055-2087. doi:10.1111/sed.12457

Murphy, A. E., Sageman, B. B., and Hollander, D. J. (2000). Eutrophication by Decoupling of the marine Biogeochemical Cycles of C, N, and P: a Mechanism for the Late Devonian Mass Extinction. Geology 28, 427-430. doi:10.1130/00917613(2000) 28<427:ebdotm>2.0.CO;2

Nie, T., Guo, W., Sun, Y.-L., Shen, B., Yin, B.-A., Tang, Z.-H., et al. (2016). Age and Distribution of the Late Devonian Brachiopod Genus Dzieduszyckia Siemiradzki, 1909 in Southern China. Palaeoworld 25, 600-615. doi:10.1016/ j.palwor.2016.03.005

Over, D. J. (2002). The Frasnian/Famennian Boundary in central and Eastern United States. Palaeogeogr. Palaeoclimatol. Palaeoecol. 181, 153-169. doi:10.1016/S0031-0182(01)00477-1

Percival, L. M. E., Davies, J. H. F. L., Schaltegger, U., De Vleeschouwer, D., Da Silva, A.-C., and Föllmi, K. B. (2018a). Precisely Dating the Frasnian-Famennian Boundary: Implications for the Cause of the Late Devonian Mass Extinction. Sci. Rep. 8, 9578. doi:10.1038/s41598-018-27847-7

Percival, L. M. E., Jenkyns, H. C., Mather, T. A., Dickson, A. J., Batenburg, S. J., Ruhl, M., et al. (2018b). Does Large Igneous Province Volcanism Always Perturb the Mercury Cycle? Comparing the Records of Oceanic Anoxic Event 2 and the End-Cretaceous to Other Mesozoic Events. Am. J. Sci. 318, 799-860. doi:10.2475/08.2018.01

Percival, L. M. E., Ruhl, M., Hesselbo, S. P., Jenkyns, H. C., Mather, T. A., and Whiteside, J. H. (2017). Mercury Evidence for Pulsed Volcanism during the End-Triassic Mass Extinction. Proc. Natl. Acad. Sci. USA 114, 7929-7934. doi:10.1073/pnas.1705378114

Puchkov, V., Ernst, R. E., Hamilton, M. A., Söderlund, U., and Sergeeva, N. (2016). A Devonian $>2000-K m$-Long Dolerite Dyke Swarm-belt and Associated Basalts along the Urals-Novozemelian fold-belt: Part of an East-European (Baltica) LIP Tracing the Tuzo Superswell. GFF 138, 6-16. doi:10.1080/ 11035897.2015 .1118406

Qie, W., Ma, X., Xu, H., Qiao, L., Liang, K., Guo, W., et al. (2019). Devonian Integrative Stratigraphy and Timescale of China. Sci. China Earth Sci. 62, 112-134. doi:10.1007/s11430-017-9259-9

Quémerais, B., Cossa, D., Rondeau, B., Pham, T. T., and Fortin, B. (1998). Mercury Distribution in Relation to Iron and Manganese in the Waters of the St. Lawrence River. Sci. Total Environ. 213, 193-201. doi:10.1016/s0048-9697(98) 00092-8

Racki, G. (2020). A Volcanic Scenario for the Frasnian-Famennian Major Biotic Crisis and Other Late Devonian Global Changes: More Answers Than Questions? Glob. Planet. Change 189, 103174. doi:10.1016/ j.gloplacha.2020.103174

Racki, G. (2021). Big 5 Mass Extinctions. Encyclopedia Geology. 44, 603-616. doi:10.1016/b978-0-12-409548-9.12028-7

Racki, G., Rakociński, M., Marynowski, L., and Wignall, P. B. (2018). Mercury Enrichments and the Frasnian-Famennian Biotic Crisis: A Volcanic Trigger Proved? Geology 46, 543-546. doi:10.1130/G40233.1

Ricci, J., Quidelleur, X., Pavlov, V., Orlov, S., Shatsillo, A., and Courtillot, V. (2013). New 40Ar/39Ar and K-Ar Ages of the Viluy Traps (Eastern Siberia): Further Evidence for a Relationship with the Frasnian-Famennian Mass Extinction. Palaeogeogr. Palaeoclimatol. Palaeoecol. 386, 531-540. doi:10.1016/ j.palaeo.2013.06.020

Sandberg, C. A., Morrow, J. R., and Ziegler, W. (2002). Late Devonian Sea-Level Changes, Catastrophic Events, and Mass Extinctions. Geol. Soc. Am. Spec. Pap. 356, 473-487. doi:10.1130/0-8137-2356-6.473

Sanei, H., Grasby, S. E., and Beauchamp, B. (2012). Latest Permian Mercury Anomalies. Geology 40, 63-66. doi:10.1130/G32596.1

Scaife, J. D., Ruhl, M., Dickson, A. J., Mather, T. A., Jenkyns, H. C., Percival, L. M. E., et al. (2017). Sedimentary Mercury Enrichments as a Marker for Submarine Large Igneous Province Volcanism? Evidence from the Mid-cenomanian Event and Oceanic Anoxic Event 2 (Late Cretaceous). Geochem. Geophys. Geosyst. 18, 4253-4275. doi:10.1002/2017gc007153

Schoene, B., Eddy, M. P., Samperton, K. M., Keller, C. B., Keller, G., Adatte, T., et al. (2019). U-pb Constraints on Pulsed Eruption of the Deccan Traps across the End-Cretaceous Mass Extinction. Science 363, 862-866. doi:10.1126/ science.aau 2422

Schumacher, B. A. (2002). Methods for the Determination of Total Organic Carbon (TOC) in Soils and Sediments. Washington, DC: U.S. Environmental Protection Agency. EPA/600/R-02/069 (NTIS PB2003-100822).

Shen, J., Chen, J., Algeo, T. J., Yuan, S., Feng, Q., Yu, J., et al. (2019). Evidence for a Prolonged Permian-Triassic Extinction Interval from Global marine Mercury Records. Nat. Commun. 10, 1-9. doi:10.1038/s41467-019-09620-0

Shen, J., Feng, Q., Algeo, T. J., Liu, J., Zhou, C., Wei, W., et al. (2020). Sedimentary Host Phases of Mercury ( $\mathrm{Hg}$ ) and Implications for Use of $\mathrm{Hg}$ as a Volcanic Proxy. Earth Planet. Sci. Lett. 543, 116333. doi:10.1016/j.epsl.2020.116333

Shen, W., Sun, Y., Lin, Y., Liu, D., and Chai, P. (2011). Evidence for Wildfire in the Meishan Section and Implications for Permian-Triassic Events. Geochimica et Cosmochimica Acta 75, 1992-2006. doi:10.1016/j.gca.2011.01.027

Stanley, S. M. (2016). Estimates of the Magnitudes of Major marine Mass Extinctions in Earth History. Proc. Natl. Acad. Sci. USA 113, E6325-E6334. doi:10.1073/pnas.1613094113

Them, T. R., Jagoe, C. H., Caruthers, A. H., Gill, B. C., Grasby, S. E., Gröcke, D. R., et al. (2019). Terrestrial Sources as the Primary Delivery Mechanism of Mercury to the Oceans across the Toarcian Oceanic Anoxic Event (Early Jurassic). Earth Planet. Sci. Lett. 507, 62-72. doi:10.1016/j.epsl.2018.11.029

Thibodeau, A. M., Ritterbush, K., Yager, J. A., West, A. J., Ibarra, Y., Bottjer, D. J., et al. (2016). Mercury Anomalies and the Timing of Biotic Recovery Following the End-Triassic Mass Extinction. Nat. Commun. 7, 11147. doi:10.1038/ ncomms 11147

Uddin, M. K. (2017). A Review on the Adsorption of Heavy Metals by clay Minerals, with Special Focus on the Past Decade. Chem. Eng. J. 308, 438-462. doi:10.1016/j.cej.2016.09.029

Wang, Y., and Chen, H. (1999). New Data on the Frasnian-Famennian Event Boundary in the Dushan Area, South Guizhou. J. Stratigr., 23, 26-30.

Wang, Y., Wang, X., and Shi, X. (2006). Pioneer Organisms after F-F Mass Extinction in Dushan Region, Guizhou Province, and Their Significance in Establishing New Ecosystem. Sci. China Ser. D 49, 449-460. doi:10.1007/s11430-006-0449-7

Winter, J. (2015). Volcanism and Kellwasser Crisis - Zircon Tephrostratigraphy, Identification and Origin of Distal Fallout Ash Layers (Upper Devonian, Dinant Syncline, Rhenish Slate Mountains, Harz Mountains). $z d g g$ 166, 227-251. doi:10.1127/1860-1804/2015/0092

Zhang, J., Ye, T., Li, S., Yuan, G., Dai, C., Zhang, H., et al. (2016). The Provenance and Tectonic Setting of the Lower Devonian sandstone of the Danlin Formation in Southeast Yangtze Plate, with Implications for the Wuyi-Yunkai Orogeny in South China Block. Sediment. Geology. 346, 25-34. doi:10.1016/j.sedgeo.2016.10.004

Zhang, L., Chen, D., Kuang, G., Guo, Z., Zhang, G., and Wang, X. (2020). Persistent Oxic Deep Ocean Conditions and Frequent Volcanic Activities during the Frasnian-Famennian Transition Recorded in South China. Glob. Planet. Change 195, 103350. doi:10.1016/j.gloplacha.2020.103350

Zhang, X., Joachimski, M. M., Over, D. J., Ma, K., Huang, C., and Gong, Y. (2019). Late Devonian Carbon Isotope Chemostratigraphy: A New Record from the Offshore Facies of South China. Glob. Planet. Change 182, 103024. doi:10.1016/ j.gloplacha.2019.103024

Zhao, X. (1985). "Palaeogeographic Map of the Late Devonian of China," in Atlas of the Palaeogeography of China. Editor H. Wang (Beijing: Cartographic Publishing House), 65.

Conflict of Interest: The authors declare that the research was conducted in the absence of any commercial or financial relationships that could be construed as a potential conflict of interest.

Copyright (c) 2021 Zhang, Deng, Liu, Tang, Wang, Ye, Liang and Liu. This is an open-access article distributed under the terms of the Creative Commons Attribution License (CC BY). The use, distribution or reproduction in other forums is permitted, provided the original author(s) and the copyright owner(s) are credited and that the original publication in this journal is cited, in accordance with accepted academic practice. No use, distribution or reproduction is permitted which does not comply with these terms. 